\title{
木造スペースフレームの線形弾性解析に及ぼす部材軸剛性の ばらつきの影響に関する研究 \\ STUDY ON EFFECT OF DISPERSION OF AXIAL STIFFNESS OF MEMBERS ON LINEAR ELASTIC ANALYSIS OF WOODEN PREFABRICATED TRUSS
}

\author{
瀧野敦夫*1, 今井克彦*2, 畔柳 歩*3 \\ Atsuo TAKINO, Katsuhiko IMAI and Ayumu KUROYANAGI
}

\begin{abstract}
A wooden prefabricated truss system utilizing Japanese medium- and low-quality timbers has been developed in order to promote the effective use of these timbers. The purpose of this study is to evaluate the effect of the dispersion of stiffness of members on the stress magnitude and displacement in designing the wooden prefabricated truss. Monte Carlo analysis revealed the maximum stress of the members to be 1.2 times greater than the stress analyzed by the standard Young's modulus $\left(E_{0}\right)$ due to the dispersion of Young's modulus. The maximum displacement of nodes is also greater than the displacement analyzed by $E_{0}$. It is suitable to use the $5 \%$ lower limit of Young's modulus based on full-size tests of timbers considering the deformation of nodes.
\end{abstract}

Keywords : Wooden prefabricated truss, Dispersion, Stiffness of members, Young's modulus, Monte Carlo method 木造スペースフレーム, ばらつき, 部材軸剛性, ヤング係数, モンテカルロ法

\section{1.はじめに}

筆者らは，木材利用促進の一手法として，国産心持ち木材を用い た木造スペースフレームシステムの開発を行っている ${ }^{1) 〜 5) 。 ス ヘ ゚ ー ~}$ スフレーム部材には，一般の木材市場に大量に流通している中品 質の心持ち一等材を用いている。しかし，これらの木材のほとんど が一般に欠点と言われている節や乾燥龟裂を材表面に多く有してお り，強度やヤング係数に関する品質管理も特に行われていない。大 規模木造建築物に使われることが多い集成材では，ラミナの曲げヤ ング係数を実測することにより木材のヤング係数のばらつきを制御 しているが，製材品に対しては，打撃音法によるヤング係数の推定

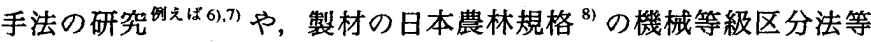
の品質管理に関する研究や規格類があるにも関わらず，実際の現場 における普及度は非常に低い。

木材は, 強度やヤング係数といった材料特性に関して非常にばら つきの大きい材料である。一般の構造解析において, 部材の軸剛性 は部材応力や変形を決定する重要な変数であるため, 軸剛性のばら つきが及ぼす影響について数值的に評価することは非常に重要なこ とである。そこで, 本研究では既に筆者らが行っている実大材料試 験 ${ }^{9), 10)}$ や接合部実大試験 ${ }^{4) .5)}$ の結果に基づき，木材のヤング係数や 接合部変形のばらつきを考慮したモンテカルロ法による線形弾性解
析を行い，部材の軸剛性のばらつきが及ぼす部材応力や変形への影 響について検証する。

\section{2. 解析方法}

\section{1 木材のヤング係数}

木質構造設計規準・同解説 ${ }^{11}$ （以下，設計規準と呼ぶ）及び木質 構造限界状態設計指針 (案) ·同解説 ${ }^{22}$ (以下, 限界指釬と呼ぶ) には, ヤング係数に関してそれぞれ次の記述がある。

設計規準:「そこで, 樹種ごとの弾性係数の分布を正規分布と仮定し， 以下の式によって，信頼水準 75\% における50\% 下側許容限界值を 算出し, (以下略)」

限界指針：「木材強度, 弾性係数, 接合耐力のそれぞれの分布は 2 母数ワイブル分布（2P ワイブル分布）を採用することとした。」 そこで本論では，これらの規準類に基づき正規分布と 2 母数ワイブ ル分布の $2 つ の$ 分布形について乱数を発生させ，検討を行った。

筆者らが行った兵庫県産のスギ，ヒノキの心持ち材の実大試験よ り得られたヤング係数を図 1 に, 基本統計量を表 1 に示す。図中に は, ヤング係数の正規分布曲線及び 2 母数ワイブル分布曲線を併記 した。また, 設計規準に記載されている基準弾性係数 $\left(E_{0}, E_{0.05}\right.$ ) 及び正規分布と仮定した場合の信頼水準 $75 \%$ における 5\%下側許
*1 大阪大学大学院工学研究科地球総合工学専攻 助教. 工修

*2 大阪大学フロンティア研究センター 特任教授・工博

*3 (株竹中工務店 工修
Assistant Prof., Dept. of Global Architecture, Osaka Univ., M. Eng. Prof., Frontier Research Center, Osaka Univ., Dr. Eng.

Takenaka Corporation, M. Eng. 


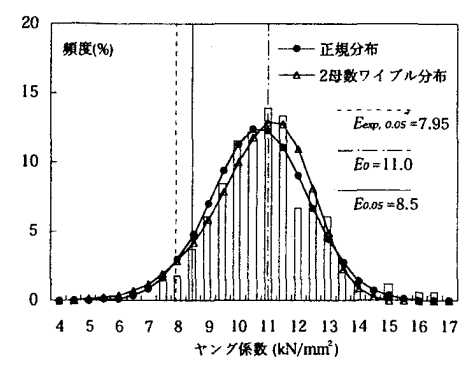

$<$ 引張・圧縮試験 $>$

$<ヒ ノ キ>$

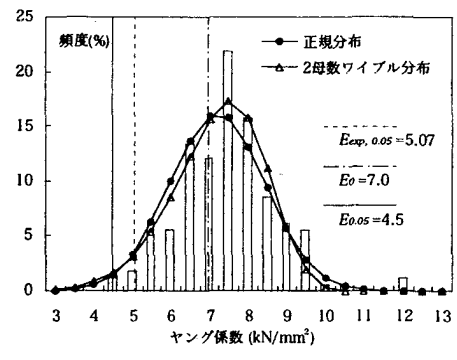

$<$ 引張・圧縮試験 $>$

くスギ>

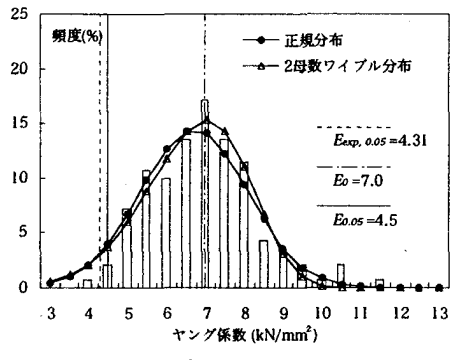

図 1 実大試験より得られた木材のヤング係数

表 1 実大試験より得られた木材のヤング係数の基本統計量

\begin{tabular}{|c|c|c|c|c|c|c|c|c|c|}
\hline \multirow[b]{2}{*}{ 材種 } & \multirow[b]{2}{*}{ 試酫種別 } & \multirow[b]{2}{*}{ 試輸体数 } & \multirow[b]{2}{*}{$\begin{array}{c}\text { 最小值 } \\
\left(\mathrm{kN} / \mathrm{mm}^{2}\right)\end{array}$} & \multirow[b]{2}{*}{$\begin{array}{c}\text { 最大值 } \\
\left(\mathrm{kN} / \mathrm{mm}^{2}\right)\end{array}$} & \multirow{2}{*}{$\begin{array}{l}\text { 変動 } \\
\text { 保数 } \\
\text { (\%) }\end{array}$} & \multicolumn{2}{|c|}{ 正規分布 } & \multicolumn{2}{|c|}{ 2母数ワイブル分布 } \\
\hline & & & & & & $\begin{array}{c}\text { 平均值 } \\
\mu\end{array}$ & $\begin{array}{c}\text { 標㴖佰差 } \\
\sigma \\
\end{array}$ & $\begin{array}{c}\text { 尺度母数 } \\
n\end{array}$ & $\begin{array}{c}\text { 形状母数 } \\
\mathrm{m}\end{array}$ \\
\hline \multirow{2}{*}{ x* } & 引張·压縮 & 165 & 4.01 & 11.71 & 17.11 & 7.21 & 1.23 & 7.70 & 7.13 \\
\hline & 座屈 & 140 & 3.96 & .41 & 20.57 & 6.71 & 1.38 & 7.23 & 5.95 \\
\hline \multirow{2}{*}{ ヒノキ } & 引張・圧穃 & 165 & & & 14.88 & 10.71 & 1.59 & 11.37 & 7.97 \\
\hline & 坐屈 & 129 & 4.34 & 14.29 & 14.83 & 9.44 & 1.40 & 10.03 & 7.85 \\
\hline
\end{tabular}

容限界値 $\left(E_{\exp , 0.05}\right)$ も図中に併記した。なお, ヤング係数は全て の試験において, 変位計を用いて測定した軸方向変形より得られた 応力度 - ひずみ度関係曲線の直線部分の傾きから求めている。スギ, ヒノキともに座屈試験から得られたヤング係数の平均値は, 引張及 び圧縮試験から得られたヤング係数の平均值に比べて低く, 約 $90 \%$ の値となっている。

\section{2 部材モデル}

接合部詳細を図 2 に, 解析に用いた部材モデルを図 3 に示す。部 材モデルは，節点バネを考慮した線材を考え，さらにそれを一つの 線材に置換したモデルとした。線材の等価ヤング係数は, 図 4 に示 す直列モデルを考え, 引張荷重作用時と圧縮荷重作用時についてそ れぞれ次式より算出する。

$$
\begin{aligned}
{ }_{t} E_{e} & =\frac{1}{\frac{A_{w}}{n \cdot \ell}\left(\frac{1}{{ }_{t} K_{i}}+\frac{1}{{ }_{t} K_{j}}\right)+\frac{1}{E_{w}}} \\
{ }_{c} E_{e} & =\frac{E_{w}}{\frac{2.4 \cdot A_{w} \cdot \phi_{E D}}{\ell \cdot A_{E D}}+\frac{1}{\eta}}
\end{aligned}
$$

ここで, ${ }_{t} E_{e}:$ 引張荷重作用時の部材の等価ヤング係数

$A_{w}$ : 木材の断面積, $n$ : ラグスクリューの本数, $\ell$ : 節点間距離 ${ }_{t} K_{i},{ }_{t} K_{j}$ : 部材両端のラグスクリュー1 本当たりの引張バネ定数 $E_{w}:$ 木材のヤング係数

${ }_{c} E_{e}$ : 圧縮荷重作用時の部材の等価ヤング係数

$\phi_{E D}$ : エンドディスクの直径, $A_{E D}$ : エンドディスクの接触面積 $\eta:$ 座屈によるヤング係数の低滅係数 $(\eta=0.9)$

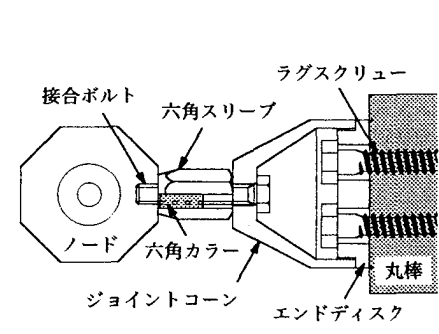

図 2 接合部詳細

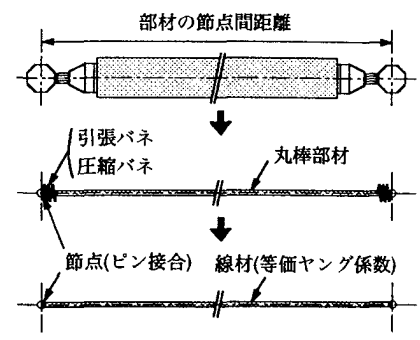

図 3 部材モデル

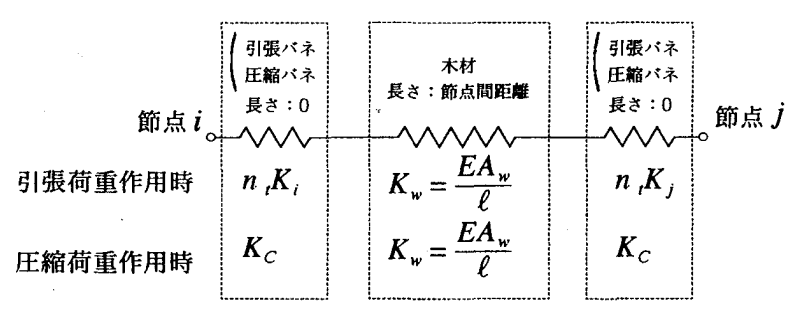

図 4 等価ヤング係数算定用の直列モデル
部材両端のラグスクリュー1本当たりの引張バネ定数（以下，引 張バネ定数と呼ぶ）は，木材のヤング係数とは相関性が低いためそ れぞれ独立した変数とした。一方，木材へのめり込み変形による圧 縮バネ定数は，木材のヤング係数とは相関性が高いため，接合部圧 縮試験より得られた次式の関係を用い，木材のヤング係数に対して 従属変数としている。

$$
K_{c}=\frac{E_{w} \cdot A_{E D}}{1.2 \cdot \phi_{E D}}
$$

ここで, $K_{c}:$ 圧縮バネ定数

なお，引張バネ及び圧縮バネのモデル化についての検討は，畔柳ら が行った接合部試験の結果 ${ }^{4) .5)(13)}$ を参照した。

\section{3 許容耐力}

部材の許容耐力は, 部材, 接合部における各要素の耐力を比較検 討し, 最小となる值から引張部材及び圧縮部材についてそれぞれ決 定している。現行のシステムにおいて，接合金物，木材の丸棒径や ラグスクリュー本数との組み合わせを考慮すると, 引張部材はラグ スクリュー引抜き耐力が, 圧縮部材は木材の座屈耐力とエンドディ スク接触面の木材の圧縮耐力のうちの小さい方が許容耐力となる。 エンドディスク接触面における木材の圧縮破壊は, 粘りのある破壊 性状を示すが，ラグスクリュー引抜き破壊及び木材の座屈破壊は， ともに脆性的な破壊を生じることから，引張部材及び圧縮部材は降 伏域を持たない弾性部材と仮定した。

部材の短期許容耐力 $f_{1}$ は, 次式より求めた。

$$
f_{t}=\frac{2}{3} F
$$

ここで, $F$ : 基準強度

各破壊性状に対応する基準強度は, 実大試験の結果 ${ }^{91.101}$ から求め た信頼水準 75\%における5\% 下側許容限界值を基に決定しており, 圧縮部材については, 設計規準に記載されている甲種構造材 3 級の 值を基に各々の許容耐力を算出している。

\section{4 解析モデル}

解析モデルは，実際の木造スペースフレームシステムの設計手順 
に従って決定した。解析モデルを図 5, 図 6 に示す。形状は, 圧縮 卓越型のアーチ状二層立体トラス構造（以下，アーチトラスと呼 ぶ）と梁型の平板状二層立体卜ラス構造（以下, 平板トラスと呼ぶ） の 2 種類とした。アーチトラスは, スパン $40 \mathrm{~m}$, ライズ $5 \mathrm{~m}$ のもの を基本形状とし，基本形状からライズを $5 \mathrm{~m}$ ずつ上げたものの合計

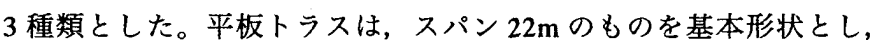
基本形状より $2 \mathrm{~m}$ ずつスパンを変化させたものの合計 3 種類とし た。使用した部材一覧を表 2 に, 部材長の平均值及び細長比の平均 值を表 3 及び表 4 に示す。表内に示す “X 方向下弦材端部” とは, $X$ 方向の下弦材の両端 3 モジュールずつを表し, “X 方向下弦材一 般部”とは, $\mathrm{X}$ 方向の下弦材の両端 3 モジュール以外の部分を表す。 ラグスクリューの有効ネジ長さは, M12 の場合 $170 \mathrm{~mm}, \mathrm{M} 16$ の場 合 $235 \mathrm{~mm}$ である。また, 表 3 及び表 4 に各部材の圧縮時における 許容耐力を併記した。“座屈”は, 木材の座屈耐力を示し, “E-disk” はエンドディスク接触面の木材の圧縮酎力を示す。アーチトラスは 両端ピン支持とし, 平板トラスは片側ピン，片側ローラー支持とし た。

荷重条件は, 「固定荷重 + 地震荷重 (以下, D+K と呼ぶ)」と「固 定荷重 + 積雪荷重 (以下, D+S と呼ぶ)」の 2 種類とし, 表 5 に示 す荷重条件を設定した。荷重は, トラス上面の見付面積に基づき算 定し，全て上弦節点に節点荷重として与えた。

表 2 使用部材一覧

\begin{tabular}{|c|c|c|c|c|}
\hline 形状 & 位置 & $\begin{array}{c}\text { 接合金物形状 } \\
\text { (接合金物径)-(接合ボルト经) }\end{array}$ & $\begin{array}{c}\text { ラグスクリュー } \\
\text { (ラグスクリュー径)-(本数) }\end{array}$ & $\begin{array}{l}\text { 丸棒径 } \\
\text { (木材) }\end{array}$ \\
\hline \multirow{6}{*}{$\begin{array}{l}\text { アーチ } \\
\text { トラス }\end{array}$} & 上弦材Y方向 & $\phi 92-\mathrm{M} 12$ & M12 $2 \times 3$ & $\phi 120$ \\
\hline & 上弦材X方向 & $\phi 110-\mathrm{M} 16$ & M16 64 & $\phi 150$ \\
\hline & 下弦材Y方向 & $\phi 92-\mathrm{M} 12$ & $\mathrm{M} 12 \times 3$ & $\phi 120$ \\
\hline & $\mathrm{X}$ 方向下弦材端部 & $\phi 140-\mathrm{M} 20$ & $\mathrm{M} 16 \times 3$ & $\phi 180$ \\
\hline & X方向下弦材一般部 & $\phi 110-\mathrm{M} 16$ & MI6×4 & $\phi 150$ \\
\hline & ウェブ & $\phi 92-\mathrm{M} 12$ & $\mathrm{M} 12 \times 3$ & $\phi 120$ \\
\hline \multirow{5}{*}{$\begin{array}{l}\text { 平板 } \\
\text { トラス }\end{array}$} & 上弦材Y方向 & $\phi 92-\mathrm{M} 12$ & $\mathrm{M} 12 \times 3$ & $\phi 120$ \\
\hline & 上弦材X方向 & $\phi 110-\mathrm{M} 16$ & M16×4 & $\phi 150$ \\
\hline & 下苪材Y方向 & $\phi 92-\mathrm{Ml} 2$ & $\mathrm{M} 12 \times 3$ & $\phi 120$ \\
\hline & 下弦材X方向 & $\phi 167-\mathrm{M} 24$ & MI $6 \times 8$ & $\phi 210$ \\
\hline & ウェブ & $\phi 92-\mathrm{Ml2}$ & $\mathrm{M} 12 \times 3$ & $\phi 120$ \\
\hline
\end{tabular}

\section{5 乱数}

一つの解析ごとに独立した 3 個の乱数を部材の数だけ発生させ, 式 (1) 及び式 (2)における木材のヤング係数 $\left(E_{w}\right)$, 引張バネ定 数 $\left({ }_{i} K_{i},{ }_{i} K_{j}\right)$ にそれぞれ割り当てる。乱数の発生は, Numerical
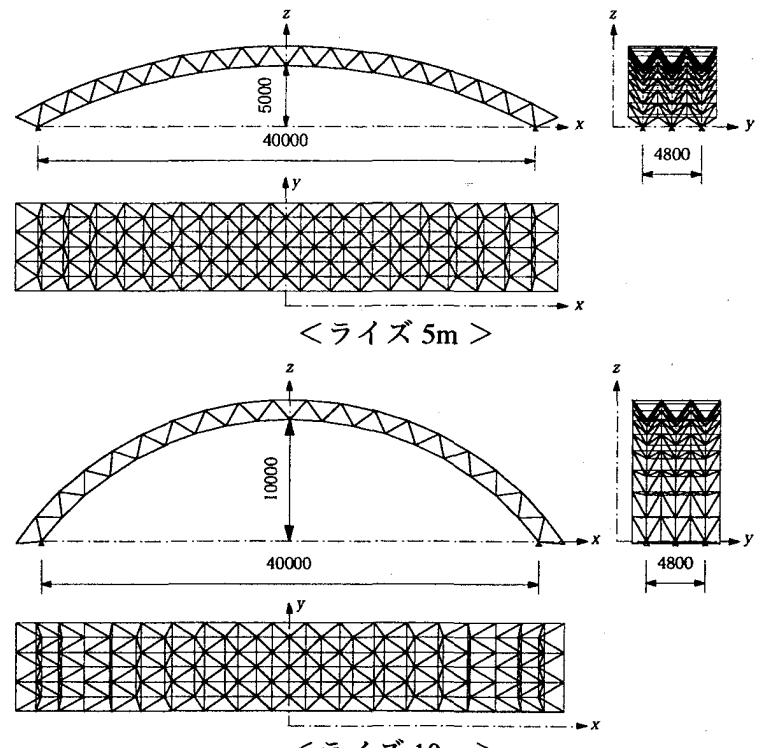

くライズ $10 \mathrm{~m}>$
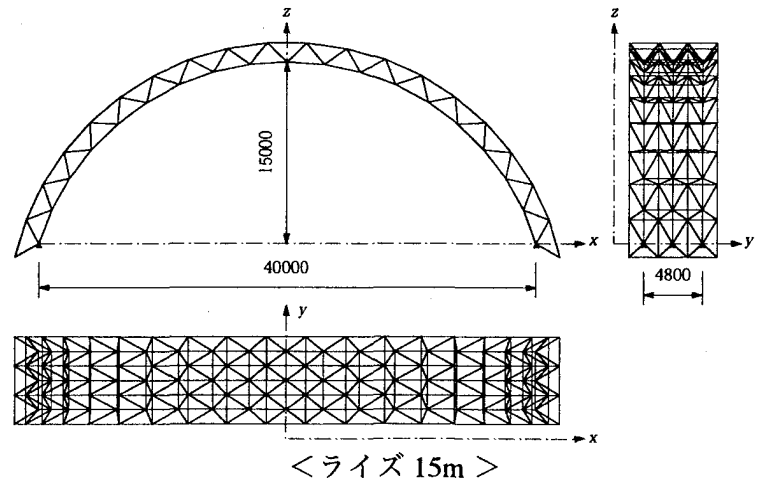

図 5 解析モデル (アーチトラス)
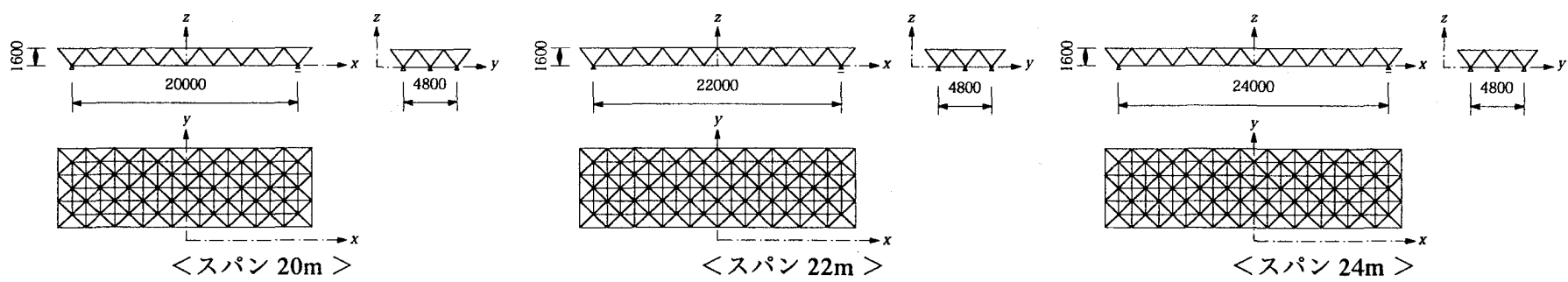

図 6 解析モデル (平板トラス)

表 3 部材長の平均値及び細長比の平均值の一覧（アーチトラス）

\begin{tabular}{|c|c|c|c|c|c|c|c|c|c|c|c|c|c|c|c|c|c|c|}
\hline & \multicolumn{6}{|c|}{ アーチトラス (ライズ: $5 \mathrm{~m})$} & \multicolumn{6}{|c|}{ アーチトラス (ライズ：10m) } & \multicolumn{6}{|c|}{ アーチトラス (ライズ：15m) } \\
\hline & \multicolumn{2}{|c|}{ 上弦材 } & \multicolumn{3}{|c|}{ 下弦材 } & \multirow{2}{*}{ ウェブ } & \multicolumn{2}{|c|}{ 上弦材 } & \multicolumn{3}{|c|}{ 下弦材 } & \multirow{2}{*}{ ウェブ } & \multicolumn{2}{|c|}{ 上弦材 } & \multicolumn{3}{|c|}{ 下弦材 } & \multirow{2}{*}{ ウェブ } \\
\hline & $\mathrm{X}$ 方向 & Y方向 & X方向端部 & $\mathrm{X}$ 方向一般部 & Y方向 & & $\mathrm{X}$ 方向 & Y方向 & $\mathrm{X}$ 方向端部 & $\mathrm{X}$ 万向一般部 & Y方向 & & $\mathrm{X}$ 方向 & Y方向 & $\mathrm{X}$ 方向端部 & $\mathrm{X}$ 方向一般部 & Y方向 & \\
\hline 部材入 & 76 & 60 & 18 & 36 & 38 & 228 & 76 & 60 & 18 & 36 & 38 & 228 & 76 & 60 & 18 & 36 & 38 & 228 \\
\hline 部材長 (平均值) & 2400.5 & 2400.0 & 2313.4 & 2313.4 & 2400.0 & 2321.3 & 2739.5 & 2400.0 & 2574.7 & 2574.7 & 2400.0 & 2400.9 & 3205.2 & 2400.0 & 2976.6 & 2976.6 & 2400.0 & 2527.5 \\
\hline 紐長比 (平均值) & 64 & 80 & 51 & 62 & 80 & \begin{tabular}{|l|}
77 \\
\end{tabular} & 73 & 80 & 63 & 66 & 80 & 80 & 85 & 80 & 73 & 76 & 80 & 84 \\
\hline 許容耐力 (圧縮) & E-disk & 座屈 & E-disk & E-disk & 雪屈 & 座屈 & 座屈 & 座屈 & E-disk & E-disk & 夾屈 & 夾屈 & 來屈 & 坐屈 & 座屈 & 座屈 & 座屈 & 座屈 \\
\hline
\end{tabular}

表 4 部材長の平均值及び細長比の平均值の一覧（平板トラス）

\begin{tabular}{|c|c|c|c|c|c|c|c|c|c|c|c|c|c|c|c|}
\hline & \multicolumn{5}{|c|}{ 平板トラス (スパン：20m) } & \multicolumn{5}{|c|}{ 平板トラス (スパン：22m) } & \multicolumn{5}{|c|}{ 平板トラス (スパン：24m) } \\
\hline & \multicolumn{2}{|c|}{ 上弦材 } & \multicolumn{2}{|c|}{ 下弦材 } & \multirow[b]{2}{*}{ ウェフフ } & \multicolumn{2}{|c|}{ 上弦材 } & \multicolumn{2}{|c|}{ 下弦材 } & \multirow{2}{*}{ ウェブ } & \multicolumn{2}{|c|}{ 上弦材 } & \multicolumn{2}{|c|}{ 下弦材 } & \multirow{2}{*}{ ウェブ } \\
\hline & $\mathrm{X}$ 方向 & Y方向 & X方向 & Y方向 & & $\mathrm{X}$ 方向 & Y方向 & $\mathrm{X}$ 方向 & Y方向 & & $\mathrm{X}$ 方向 & Y方向 & $\mathrm{X}$ 方向 & $\mathrm{Y}$ 方向 & \\
\hline 部材本数 & 36 & 30 & 24 & 18 & 108 & 40 & 33 & 27 & 20 & 120 & 44 & 36 & 30 & 22 & 132 \\
\hline 部材長 (平均値) & 2500.0 & 2400.0 & 2500.0 & 2400.0 & 2358.5 & 2444.4 & 2400.0 & 2444.4 & 2400.0 & 2343.9 & 2400.0 & 2400.0 & 2400.0 & 2400.0 & 2332.4 \\
\hline 細長比 (平均值) & 67 & 80 & 48 & 80 & 79 & 65 & 80 & 47 & 80 & 78 & 64 & 80 & 46 & 80 & 78 \\
\hline 許容酎力 (压樎) & E-disk & 坐屈 & E-disk & 座屈 & 巫屈 & E-disk & 座屈 & E-disk & 座屈 & 來屈 & E-disk & 座屈 & E-disk & 座崛 & 座屈 \\
\hline
\end{tabular}

表 5 荷重条件

\begin{tabular}{|c|c|}
\hline $\begin{array}{c}\text { 単位面積当たり } \\
\text { の自重 }\end{array}$ & $441\left(\mathrm{~N} / \mathrm{m}^{2}\right)$ \\
\hline $\begin{array}{c}\text { 単位面積当たり } \\
\text { の積雪荷重 }\end{array}$ & $784\left(\mathrm{~N} / \mathrm{m}^{2}\right)$ \\
\hline 層せん断力係数 & 0.3 \\
\hline
\end{tabular}


Technologies Random Generator for Excel (NtRand) ver.2.01 (ニュー メリカルテクノロジーズ株式会社製）を用いて行った。使用する 乱数は, 正規乱数とワイブル乱数の 2 種類とした。正規乱数は, Mersenne Twister 法 ${ }^{14)}$ ，Box-Muller 法閏え(゙15) に基づき計算し，ワイ ブル乱数は, Mersenne Twister 法, 逆関数法䱨えば ${ }^{151}$ に基づき計算した。 乱数発生に用いた統計值を表 6 に示す。木材のヤング係数は，実大 引張・圧縮試験を参照し, 引張バネ定数は, 接合部引張試験を参照 している。

\section{6 解析方法}

解析には，剛性マトリクス法を利用した汎用骨組解析ソフト Multiframe 4D (Formation Design Systems 社製) を用いて, 線形弾 性解析を行った。本論で行った解析のパラメータ一覧を表 7 に示す。 3 章で述べる各節において, 各々のパラメー夕を組み合わせた解析 を行い, 網掛けの部分についての比較検討を行った。“乱数割当て 変数”の闌において, $E_{w},{ }_{i} K_{i},{ }_{t} K_{j}$ のいずれかの内, 表内に記載 している変数にのみ乱数を割当て, それ以外の変数には表 8 に示す 設計用基準值を全ての部材に与え, 解析を行った。各解析ごとに 100 サンプルずつ解析を行った。

\section{3. 結果と考察}

\section{1 乱数種別による影響}

乱数に正規乱数及びワイブル乱数を用いた場合の結果を比較した 正規化順位曲線を図 7, 図 8 に示す。変数は, 木材のヤング係数の みとした。ここで最大軸力部材の軸力比とは，応力解析により発生 した軸力が最大であった部材における短期許容耐力に対する軸力の 比の值のことである。なお図中に示す破線は，木材のヤング係数， 引張バネ定数ともに定数として解析した場合の結果（以下，基準值 と呼ぶ）である。剛性マトリクス法では, 各節点での力の分配は部
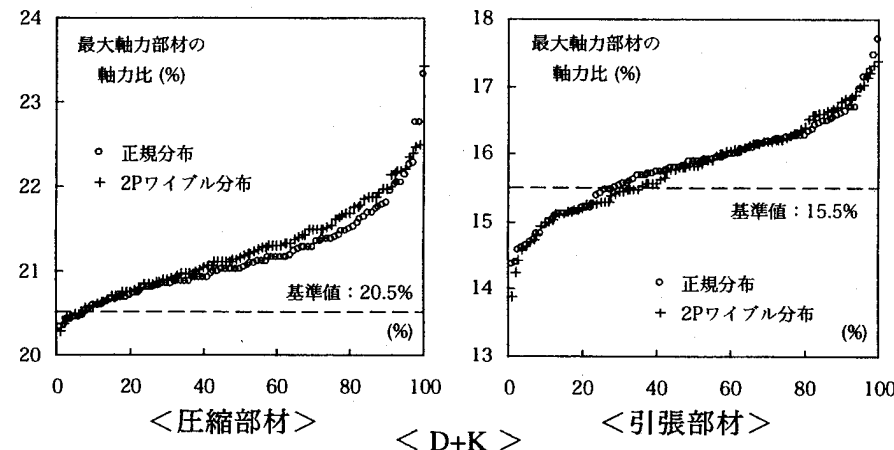

材の剛性に比例して行われるため，一様に均一なヤング係数を与え た場合に比べ，ばらつきを考慮したモデルの方が全体的に最大軸力 が増加する傾向にある。最も増大した軸力比は, 基準値と比べ 2 割 程度高い值となっている。しかし，ほほ全ての場合において正規乱 数とワイブル乱数の違いによる結果に大きな差は見られなかった。 図 1 において, 正規分布曲線と 2 母数ワイブル分布曲線の違いは非 常に小さく，どちらの分布曲線も材料試験の分布に対して誤差を生 じていることを考慮すると, 解析において正規乱数とワイブル乱数 を用いる差はほとんどないと考えられる。そのため，材料試験より 得られたヤング係数の分布は，一般的な分布曲線である正規分布と 仮定すればよいと言える。

表 6 乱数の発生に用いた統訫値

\begin{tabular}{|c|c|c|c|c|c|c|}
\hline \multirow{2}{*}{ 材種 } & \multirow{2}{*}{\multicolumn{2}{|c|}{ 変数 }} & \multicolumn{2}{|c|}{ 正規乱数 } & \multicolumn{2}{|c|}{ ワイブル乱数 } \\
\hline & & & 平均値 & 標淮偏差 & 尺度母数 & 形状母数 \\
\hline スキ & $E$ & & 7.21 & 1.23 & - & - \\
\hline \multirow{3}{*}{ ヒノキ } & \multicolumn{2}{|c|}{$E_{\mathrm{w}}$} & 10.71 & 1.59 & 11.37 & 7.97 \\
\hline & \multirow{2}{*}{${ }_{a} K_{i,}, K_{j}$} & M12 & 93.67 & 16.69 & - & - \\
\hline & & MI6 & 111.26 & 14.44 & - & - \\
\hline
\end{tabular}

表 7 解析パラメータ一覧

\begin{tabular}{|c|c|c|c|c|c|}
\hline 䈱 & 形状 & 荷重条件 & 木材材锺 & 乱数剨当て夜数 & 乱数種別 \\
\hline 3.1 & $\begin{array}{l}\text { アーチ. } 5 \\
\text { 平板 } \cdot 22\end{array}$ & $\begin{array}{l}\mathrm{D}+\mathrm{K} \\
\mathrm{D}+\mathrm{S}\end{array}$ & ヒノキ & $E_{w}$ & 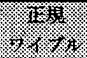 \\
\hline 3.2 & $\begin{array}{l}\text { アーチ・5 } \\
\text { 平板 } \cdot 22\end{array}$ & $\begin{array}{l}\mathrm{D}+\mathrm{K} \\
\mathrm{D}+\mathrm{S}\end{array}$ & ヒノキ & 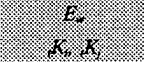 & 正規 \\
\hline 3.3 & (1) & $\begin{array}{l}\mathrm{D}+\mathrm{K} \\
\mathrm{D}+\mathrm{S}\end{array}$ & 七ノキ & $E_{w}$ & 正規 \\
\hline 3.4 & $\begin{array}{l}\text { アーチ・5 } \\
\text { 平板 } \cdot 22\end{array}$ & $\begin{array}{l}D+K \\
D+S\end{array}$ & 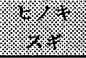 & $E_{\mathrm{w}}$ & 正規 \\
\hline
\end{tabular}

表 8 設計用基準值

\begin{tabular}{|c|c|c|c|}
\hline \multirow[b]{2}{*}{ 材種 } & \multirow[b]{2}{*}{$\begin{array}{c}E_{\mathrm{w}} \\
\left(\mathrm{kN} / \mathrm{mm}^{2}\right)\end{array}$} & \multicolumn{2}{|c|}{${ }_{i}{ }_{i} K_{i t}{ }_{t} K_{j}$} \\
\hline & & $\begin{array}{c}\mathrm{M} 12 \\
(\mathrm{kN} / \mathrm{mm})\end{array}$ & $\begin{array}{c}\mathrm{M} 16 \\
(\mathrm{kN} / \mathrm{mm})\end{array}$ \\
\hline スキ & 7.0 & 80.0 & 100.0 \\
\hline 七ノキ & 11.0 & 80.0 & 100.0 \\
\hline
\end{tabular}
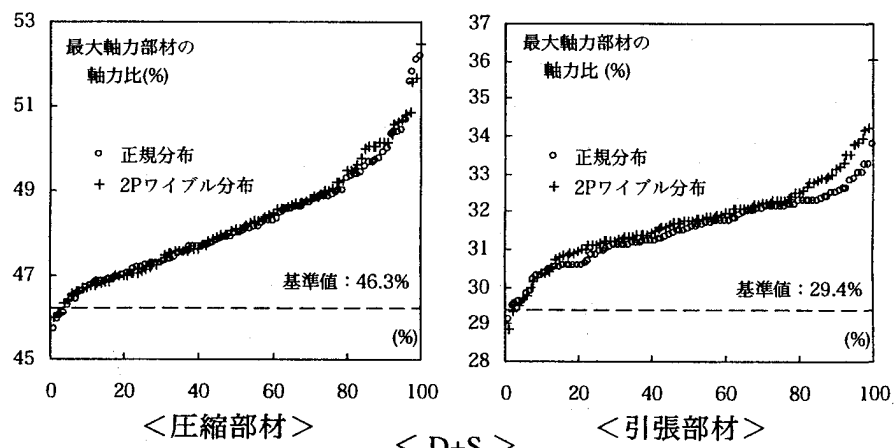

$<\mathrm{D}+\mathrm{S}>\quad<$ 引張部材 $>$

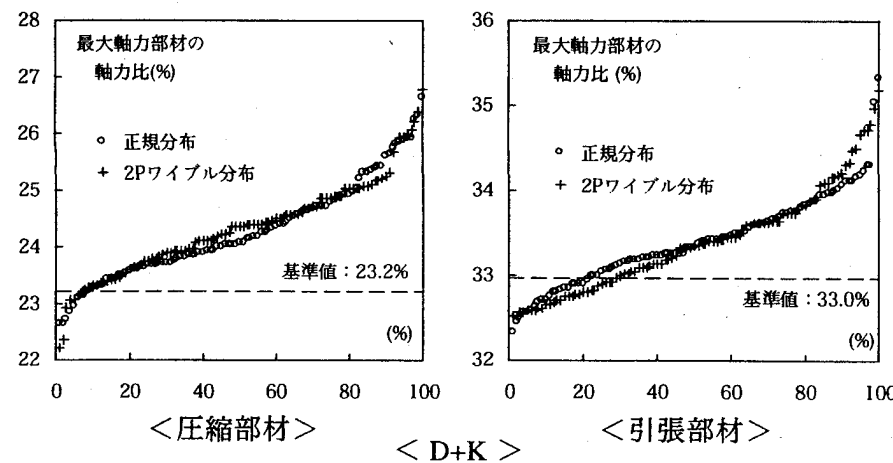

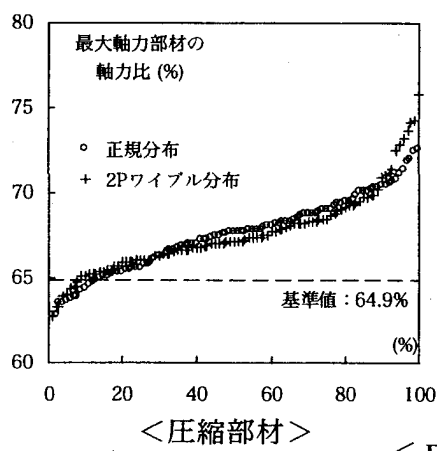

$<\mathrm{D}+\mathrm{S}>$

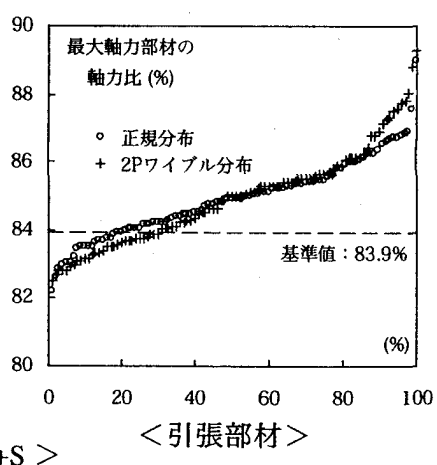

図 8 乱数種別による最大軸力部材の軸力比の正規化順位曲線（平板トラス・スパン $22 \mathrm{~m} /$ 変数 : 木材のヤング係数） 


\section{2 節点バネの影響}

木材のヤング係数及び引張バネ定数のどちらか一方あるいはその 両方を変数とした場合を比較した正規化順位曲線の一例を図 9 に, 標準的な部材における各要素の荷重と変形量との関係を図 10 に示 す。乱数には正規乱数を用いた。なお，図 10 の縦軸は部材の軸力 を表し，正は引張軸力を，負は圧縮軸力を示す。また，図 10 内の 破線に囲まれる範囲は，木材のヤング係数と引張バネ定数をそれぞ れ $8 \sim 13 \mathrm{kN} / \mathrm{mm}^{2}, 60 \sim 120 \mathrm{kN} / \mathrm{mm}$ の範囲で変動させた場合の部材 変形の変動幅を表している。圧縮部材については，引張バネ定数の みを変数とした場合の最大軸力部材の軸力比はほとんど変動してお らず，基準值とほぼ同じ值であった。これは，圧縮バネ定数が木材 のヤング係数のみに依存した変数であるため, 引張バネ定数の影響 をほとんど受けていないことによるものである。また引張部材につ いても, 最大軸力部材の軸力比はほぼ同様の傾向が見られ，大きな 引張軸力が生じる平板トラスにおいても, 引張バネ定数のみを変数 とした場合の変動幅は非常に小さい結果となっている。これは, 図 10 に示すように, 木材のヤング係数のみを変動させた場合に比べ, 引張バネ定数のみを変動させた場合の方が荷重 - 変形関係における 変動幅が小さくなっているためであり, 引張バネ定数のばらつきが 構造物全体に及ぼす影響は非常に小さく, 設計時に特に考慮する必 要がないことが分かる。

\section{3 形状の変化による影響}

アーチトラスのライズを変化させた場合の最大軸力部材の軸力比 を比較した正規化順位曲線を図 11 に示す。変数は木材のヤング係 数のみとし，乱数には正規乱数を用いた。全てのモデルにおいて同 じ部材配置であるにも関わらず，最大軸力部材の軸力比が異なって いるのは，図12に示すように形状の違いにより軸力が最大となる 部材の位置が異なるためである。しかし，図 13 に示すように発生 した最大軸力の基準值に対する増大率で見た場合には, 全てのモデ ルにおいてほぼ同様の傾向が見られ, 最大軸力の増大率は 1 割から 2 割程度となっている。

次に，平板トラスのスパンを変化させた場合の最大軸力部材の軸 力比を比較した正規化順位曲線の一例を図 14 に, 基準值に対する 最大軸力の増大率の正規化順位曲線を図 15 に示す。変数は木材の ヤング係数のみとし，乱数には正規乱数を用いた。平板トラスにお ける最大軸力部材の発生箇所は, スパン中央部の上弦材及び下弦材 であった。アーチトラスと同様に, 最大軸力の増大率はスパンの違 いによってほとんど差が見られなかった。しかし，圧縮部材と引張
部材とを比較すると, 引張部材の方が変動幅が小さくなる傾向が見 られた。これは，図10からも分かるように本材のヤング係数だけ を変数とした場合，引張部材の方が任縮部材より部材変形の変動幅 が小さくなっているためであり，このことは式（2）を求める際に 圧縮バネ定数を木材のヤング係数の従属変数としたことに起因して いる。平板トラスはアーチトラスに比べ引張部材が多く発生するこ とからこのような傾向が平板トラスのみに見られたと考えられる。

\section{4 節点の鉛直方向変位の変動}

節点の鉛值方向変位の最大值を示した正規化順位曲線を図 16, 図 17 に示す。変数は木材のヤング係数のみとし, 乱数には正規乱 数を用いた。図中に示す実線及び破線は，木材のヤング係数を一様 に与えた場合の結果を示し, 実線が設計規準における基準弾性係 数 $\left(E_{0}, E_{0.05}\right)$ によるもので, 破線が実大引張・圧縮試験より得ら れた試験結果の $5 \%$ 下限值 $\left(E_{\exp , 0.05)}\right.$ によるものである（図 1 参 照)。解析結果は, ほぼ全ての場合において $E_{0}$ を用いて解析した結 果を上回った。 $E_{0}$ は統計値のほぼ中央値を示しているにも関わら ず, 解析結果が全て $E_{0}$ の結果を上回っていることから, 構造物全 体が局所的に低いヤング係数の影響を大きく受けていると考えられ る。また, $E_{0.05}$ を用いて解析した結果と比較すると, ヒノキでは解 析結果のほぼ上限值を示し, スギでは解析結果の上限值を大きく上

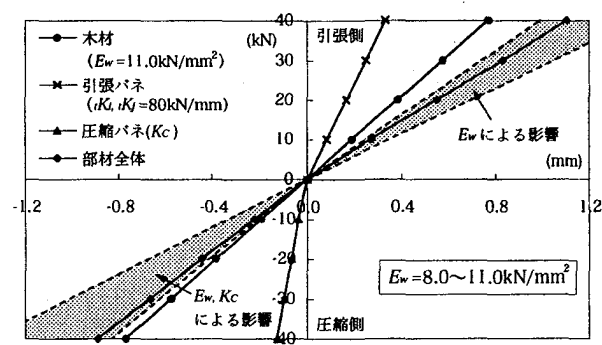

〈木材のヤング係数 $\left(E_{w}\right)$ のみを変動させた場合＞

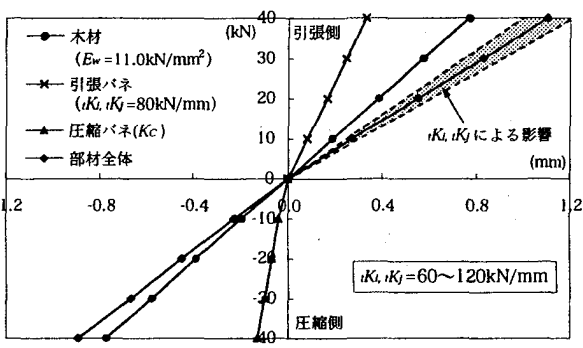

〈引張バネ定数 $\left({ }_{t} K_{i},{ }_{t} K_{j}\right)$ のみを変動させた場合＞ 図 10 標準的な部材における荷重と変形の関係
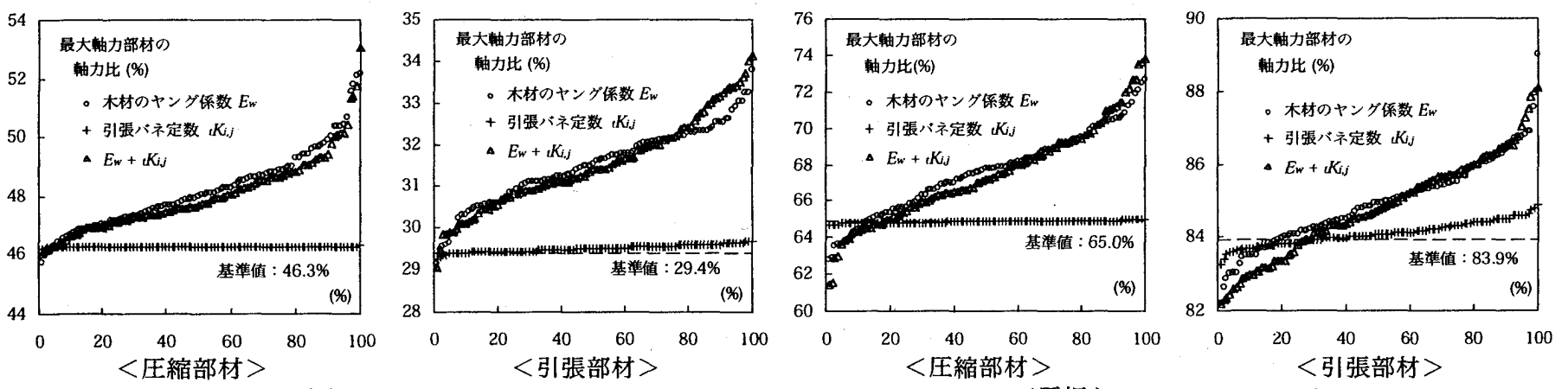

$<$ 平板トラス・ $22 \mathrm{~m} \cdot \mathrm{D}+\mathrm{S}>$

図 9 各変数ごとの解析結果による最大軸力部材の軸力比の正規化順位曲線の一例（正規乱数） 

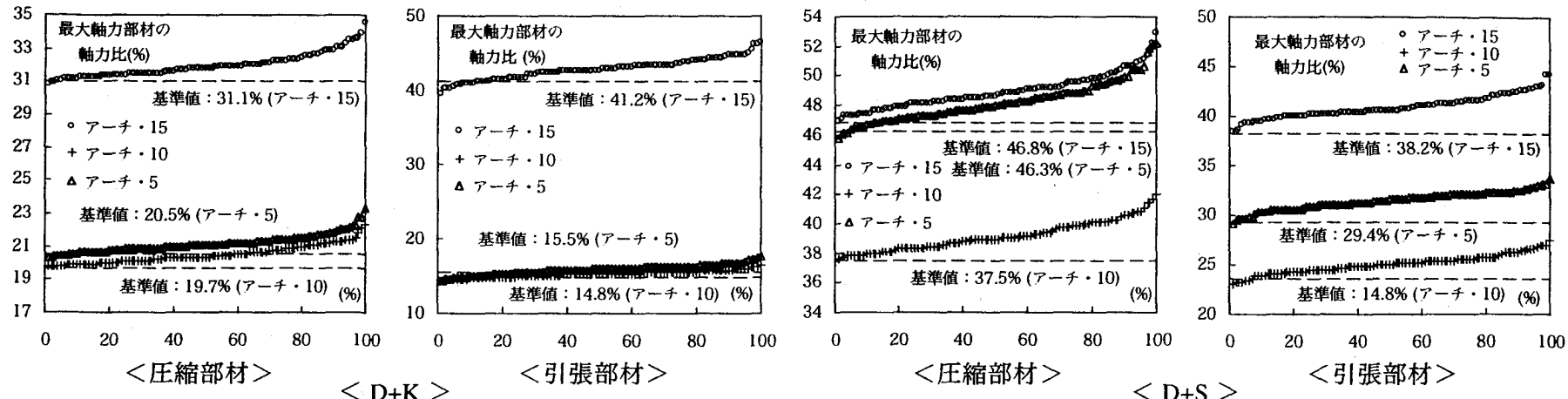

図 11 形状の違いによる最大軸力部材の軸力比の正規化順位曲線（アーチトラス/変数：木材のヤング係数・正規乱数）

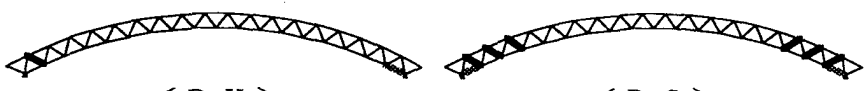

$<\mathrm{D}+\mathrm{K}>$

$<\mathrm{D}+\mathrm{S}>$

<ライズ $5 \mathrm{~m}>$

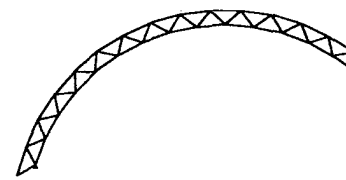

$<\mathrm{D}+\mathrm{K}>$

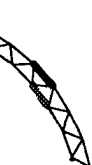

$\Delta$

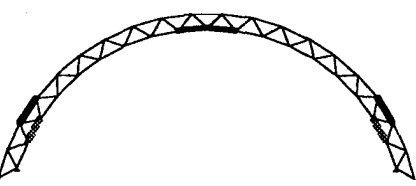

$<\mathrm{D}+\mathrm{S}>$

くライズ $15 \mathrm{~m}>$

$<\mathrm{D}+\mathrm{S}>$

：引張部材

$<\mathrm{D}+\mathrm{K}\rangle$

くライズ $10 \mathrm{~m}>$

図 12 アーチトラスにおける最大軸力部材の位置
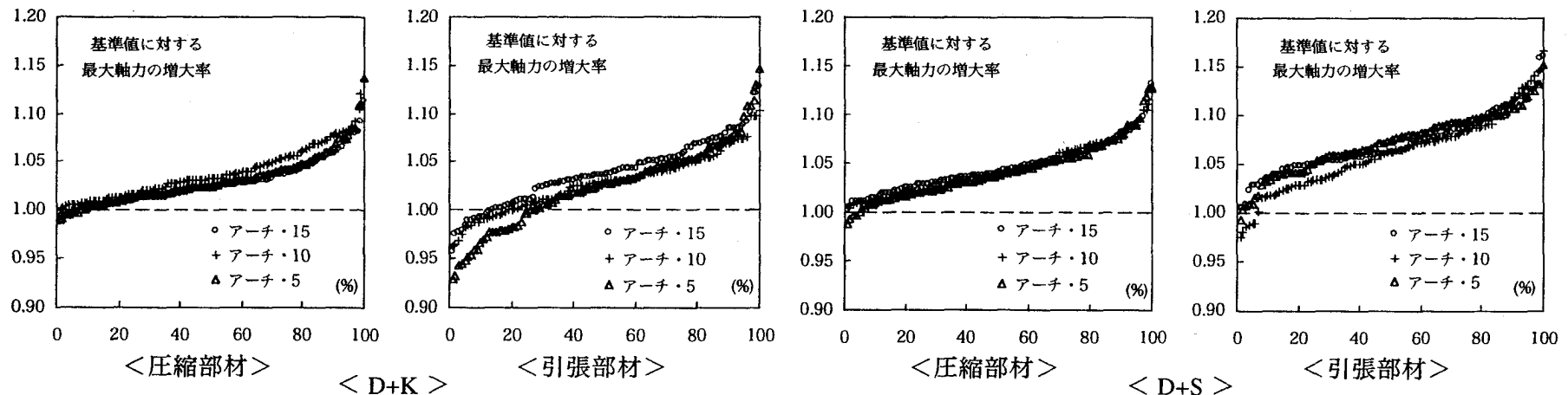

図 13 基準值に対する最大軸力の増大率の正規化順位曲線（アーチトラス/変数：木材のヤング係数・正規乱数）
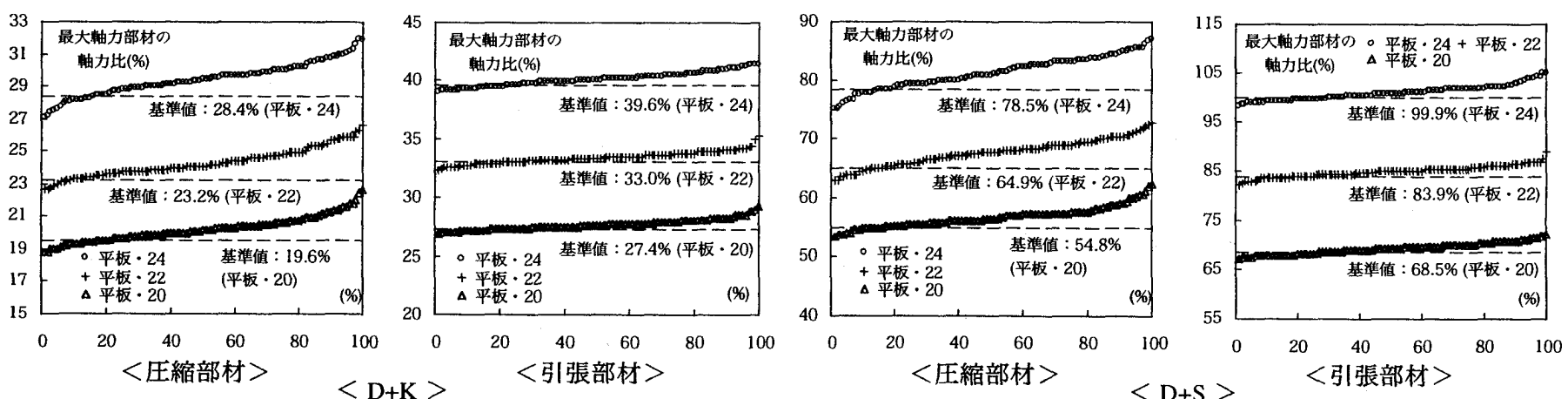

図 14 形状の違いによる最大軸力部材の軸力比の正規化順位曲線（平板トラス/変数：木材のヤング係数・正規乱数）
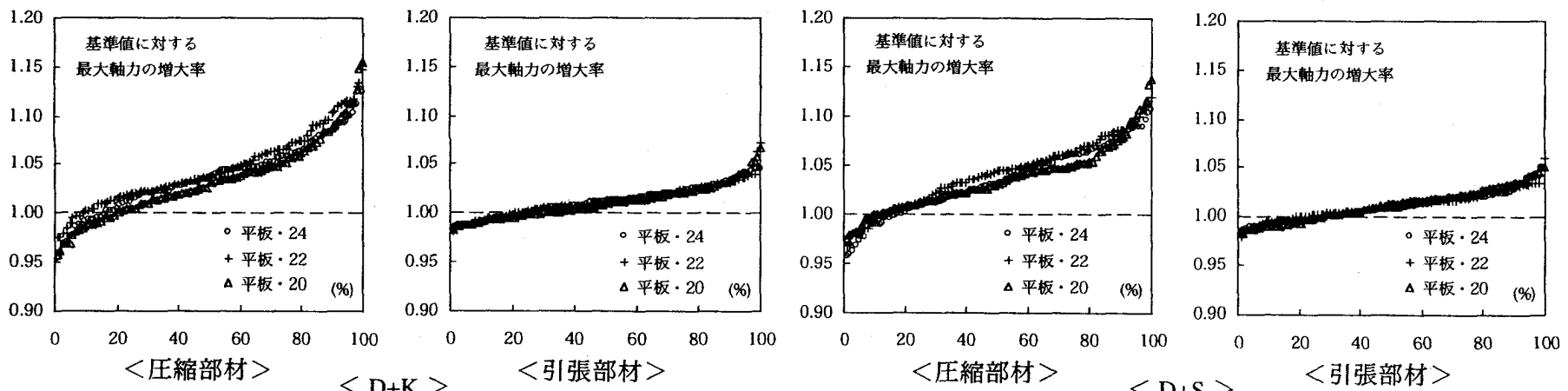

図 15 基準値に対する最大軸力の増大率の正規化順位曲線（平板トラス/変数 : 木材のヤング係数・正規乱数 

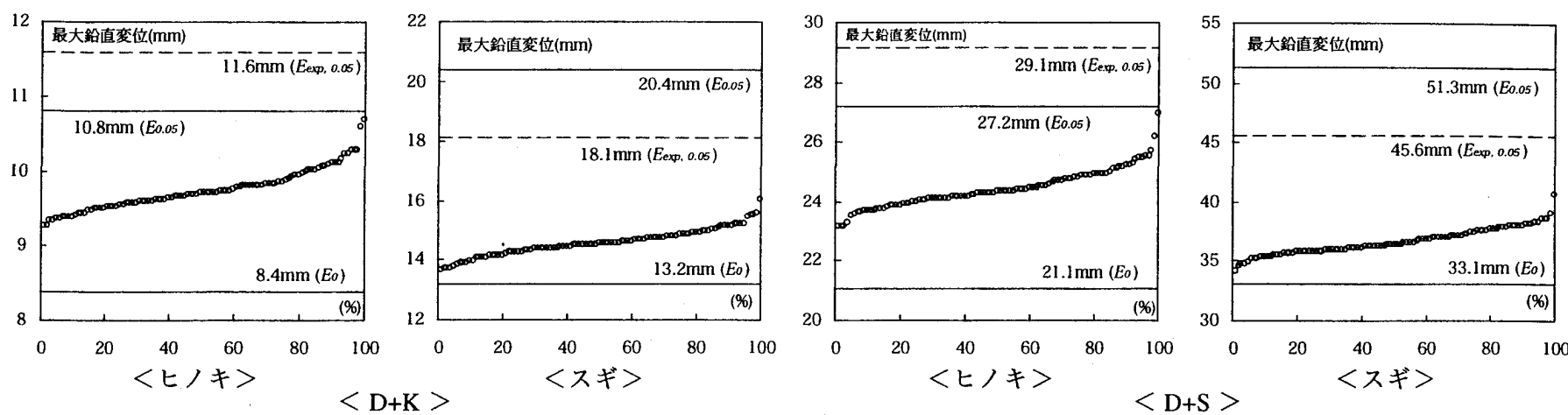

図 16 鉛直方向変位の最大值の正規化順位曲線（アーチトラス・ライズ $5 \mathrm{~m}$ )
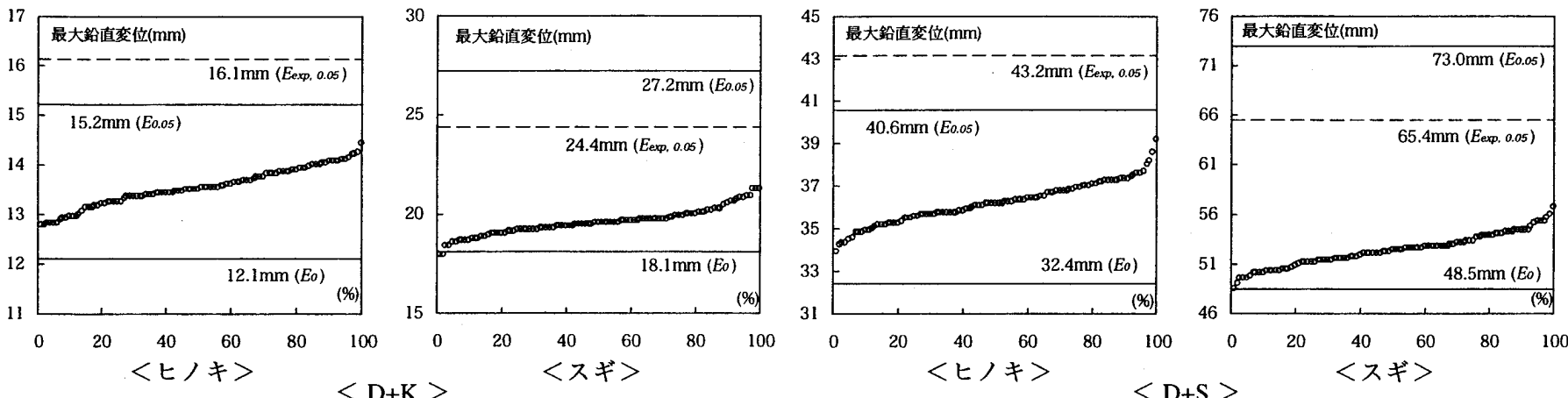

図 17 鉛直方向変位の最大值の正規化順位曲線（平板トラス・スパン $22 \mathrm{~m}$ )

回る結果となった。また， $E_{\mathrm{exp}, 0.05}$ を用いた解析結果では, ヒノキ， スギともに最大值に対して同程度の安全率を保証しており, 設計に 用いる際の妥当な数值であると言える。

\section{4. まとめ}

アーチ状二層立体トラス構造及び平板状二層立体トラス構造にお いてスペースフレーム部材の軸剛性のばらつきが設計時の応力, 変 形に与える影響についてモンテカルロ法に基づいた解析による検証 を行った。以下に結論を示す。

（1） 正規乱数, ワイブル乱数の違いによる解析結果の差はほとん ど見られなかった。材料試験より得られたヤング係数の分布は， 一般的な分布曲線である正規分布と仮定すればよい。

（2）ラグスクリュー引抜き変形による引張バネ定数のばらつきは， 解析結果にほとんど影響しない。

（3）アーチ状二層立体トラス構造物及び平板状二層立体トラス構 造物において，本論の範囲内では，形状の違いによらず木材の ばらつきによる最大軸力の設計值に対する増大率は 1 ～ 2 割程 度である。

（4）変形を検討する際は，実大材料試験より得られたヤング係数 の 5\%下限値を用いる必要がある。

\section{参考文献}

1）今井克彦, 藤田宜紀, 脇山広三, 辻岡静雄, 藤本益美, 渡辺英樹, 稲田雅宣 寺崎美智子：小中径木の材料学的基礎研究及びこれを用いた空間構造の開 発について - その $1 \sim 5$, 日本建築学会大会学術講演梗概集 C-1, ppl 〜 10, 2001.9

2）今井克彦, 藤田宜紀, 脇山広三, 辻岡静雄, 藤本益美, 秒田雅宣, 瀧野敦 夫, 福留弘子：丸太の材料基礎実験及びこれによる空間構造の開発に関す る研究 - その $1 \sim 3$, 日本建築学会大会学術講演梗概集 C-1, pp157～162,
2002.8

3) 今井克彦, 藤田宜紀, 脇山広三, 辻岡静雄, 藤本益美, 稲田雅宣, 瀧野敦夫, 福留弘子：小中径木の材料機械的特性とこれに基づくスペースフレーム の開発に関する研究 - その 1〜2, 日本建築学会大会学術講演梗概集 C-1, $\mathrm{pp} 477 \sim 480,2003.9$

4）畔柳歩, 辻岡静雄, 瀧野敦夫, 脇山広三, 今井克彦:小中径木を用いたスペー スフレーム接合部の圧縮・引張性能に関する寒験的研究 - その $1 \sim 2$, 日本 建築学会大会学術講演梗概集 C-1, pp265 268, 2005.9

5）畔柳歩, 瀧野敦夫, 片谷昌寬, 爱野将児, 辻岡静雄, 弯山広三, 今井克彦: 互換性のある接合部を有する木造スペースフレームの引張性能に関する実 験的研究, 日本建築学会大会学術講演梗概集 C-1, pp85 86, 2006.9

6）藤田晋輔, 宮内正文, 服部芳明, 山之内清竜, 馬田英隆：打撃音法による スギ製材品のヤング係数の評価法（III)，木材工業 Vol. 50 No.4，pp.160〜 $165,1995.4$

7）長尾博文, 䉆野剛三, 加藤英雄, 田中俊成：樹幹内のヤング係数分布に 基づいた製材品の強度推定 - カラマッへの試み -，木材学会誌 Vol.49 No.2, pp59 67, 2003.3

8）日本農林規格 : 木材編 - 針葉樹の構造用製材，2001.11

9）瀧野敦夫, 今井克彦, 古川忠稔, 过岡静雄, 藤本益美：国産心持与木材の 引張強度特性に関する実験的研究，日本建築学会構造系論文集 No.611, pp.119-124, 2007.1

10）瀧野敦夫, 今井克彦, 辻岡静雄 : 小中径木丸棒の座屈耐力評価に関する 実験的研究，日本建築学会構造系論文集 No.617, pp.137-143, 2007.7

11）日本建築学会 : 木質構造設計規準・同解説, 2006.12

12）日本建築学会：木質構造限界状態設計指針（案) ・同解説，2003.10

13）畔柳歩：小中径木を用いたスペースフレームの設計法に関する研究，大 阪大学大学院工学研究科修士論文, 2007.3

14) M.Matsumoto, T.Nishimura : Mersenne Twister: A623-dimensionally equidistributed uniform pseudorandom number generator, ACM Trans. on Modeling and Computer Simulation Vol.8 No.1, pp.3-30, 1998.1

15）脇本和昌：乱数の知識，森北出版株式会社，1970 